\title{
Review on the Fate and Mechanism of Nitrogen Pollutant Removal from Wastewater Using a Biological Filter
}

\author{
Honglei Wang1*, Wei Zhi ${ }^{2}$, Na Deng ${ }^{1}$, Guodong $\mathrm{Ji}^{3}$ \\ ${ }^{1}$ State Key Laboratory of Soil Erosion and Dry land Farming on the Loess Plateau, \\ Institute of Soil and Water Conservation, Northwest A \& F University, \\ Yangling 712100 , Shaanxi, China \\ ${ }^{2}$ John and Willie Leone Department of Energy and Mineral Engineering, The Pennsylvania State University, \\ University Park, Pennsylvania 16802, United States \\ ${ }^{3}$ Key Laboratory of Water and Sediment Sciences, Ministry of Education, Department of Environmental Engineering, \\ Peking University, Beijing 100871, China
}

Received: 21 December 2016

Accepted: 25 February 2017

\begin{abstract}
Biological filter (biofilter) technology has developed rapidly and has been extensively employed to remove nitrogen pollutants originating from aquatic environments. Due to the different responses of nitrogen microorganisms to various operating parameters and environmental factors, achieving satisfactory nitrogen removal in biofilters remains a challenge. Hence, this review aims to provide useful information on the underlying nitrogen removal mechanisms in biofilters by giving a comprehensive review of traditional and newly discovered nitrogen transformation processes and microbial communities associated with nitrogen cycling. Firstly, a brief summary on overall performance of biofilters using traditional and newly discovered methods for nitrogen removal was presented. The detailed nitrogen transformation pathways and functional microbial communities associated with nitrogen cycling in biofilters were discussed. A brief overview is followed by a more detailed discussion of techniques for assessing nitrogen microbial population dynamics and community structure and function. Finally, conclusions and recommendations for future work are highlighted.
\end{abstract}

Keywords: biotransformation, nitrogen removal, biofilter, wasterwater, nitrogen microorganisms

\section{Introduction}

The discharge of excessive organic matter and nitrogen into water can cause serious ecological problems such as eutrophication, algae blooms, and habitat degradation in

*e-mail: wanghonglei@pku.edu.cn aquatic environments (i.e., rivers, lakes, reservoirs, and groundwater) [1]. As in many aquatic environments, pollution is a worldwide issue, especially in developing countries. Over the last few decades, intensive economic development in developing countries has led to excess nitrogen being discharged into aquatic environments due to burgeoning industrialization, civilization, and agricultural activities [2-4]. In particular, increased nitrogen pollutant 
inflows can stimulate excessive and unbalanced growth of plants and algae, leading to oxygen depletion and eventual eutrophication of the water body [5].

A biofilter is a type of wastewater treatment system. It consists of a fixed bed of rocks, lava, coke, gravel, slag, polyurethane foam, sphagnum peat moss, ceramic, or plastic media over which sewage or other wastewater flows downward and causes a layer of microbial slime (biofilm) to grow, covering the bed of media. The systems utilize complex removal mechanisms involving filtration, adsorption, and biological degradation to remove various contaminants or improve water quality [6]. Biofilters afford many considerable advantages, including simple design and operation, low capital and operating costs, and a low requirement for energy and maintenance inputs [7]. During the past two decades, use of biofilter systems has developed rapidly, and biofilters have been widely used to remove various pollutants originating from aquatic environments [1, 8-12].

However, how to achieve satisfactory $\mathrm{NH}_{4}^{+}-\mathrm{N}$ and $\mathrm{NO}_{3}^{-}-\mathrm{N}$ removal has become an urgent issue and a research hotspot in the field of biofilters. On one hand, substrate types (i.e., plastic, mineral inert media, modified zeolite, and bioceramic) are a predominant influencing factor on nitrogen removal in biofilters. The substrates play an essential role in nitrogen adsorption and can provide optimal growing and enriching conditions for nitrogen microorganisms. On the other hand, nitrogen microbial activity is the primary reason for primary nitrogen removal. This has been a cornerstone of the technology almost from the beginning [13-14]. Due to the different responses of nitrogen microorganisms to operating parameters (free ammonia concentration, temperature, dissolved oxygen (DO), and $\mathrm{pH}$, etc.) and the complex interrelationships among various nitrogen species, achieving satisfactory nitrogen removal in biofilters remains a challenge [1, 15]. Thus, understanding the underlying microbial nitrogen transformation mechanisms under different operating conditions has extended concurrently with the use of biofilters.

While the underlying microbial nitrogen transformation mechanisms have been intensively studied, there is still a knowledge gap in the understanding of these detailed underlying mechanisms that control nitrogen removal in biofilters. Meanwhile, there are complex interrelationships among various nitrogen species (i.e., $\mathrm{NH}_{4}^{+}-\mathrm{N}, \mathrm{NO}_{3}^{-}-\mathrm{N}$, and nitrite $\left.\left(\mathrm{NO}_{2}^{-}-\mathrm{N}\right)\right)$ and also different nitrogen removal mechanisms in biofilters. Hence, an overview focusing on microbial nitrogen transformations will be helpful for researchers with the choice of appropriate microbial nitrogen removal pathways to optimize the design, operation, and application of biofilters. This paper presents the first attempt to provide an overall review on the traditional method and new aspects of microbial nitrogen removal performance using biofilters. Besides, the paper also makes a comprehensive summary of the microbial nitrogen removal processes and pathways in biofilters. Techniques for assessing nitrogen microbial communities in biofilters will also be discussed.

\section{Nitrogen Removal Performance}

Various biofilters have been designed to remove nitrogen pollution in wastewater. While there are complex interrelationships among various nitrogen species and the different responses of nitrogen microorganisms to operating parameters in biofilters, achieving high nitrogen removal performance remains a challenge. Hence, the evaluation of the removal and fate of nitrogen in various biofilters is imperative for the optimization of treatment processes. The operational adaptability and feasibility of biofilters are compared in an attempt to explore the traditional and newly discovered methods for nitrogen removal.

\section{Traditional Methods for Nitrogen Removal}

Traditional biofilters have been used to remove nitrogen pollution in aquatic environments. The traditional methods for nitrogen removal in aquatic environments have been the integration of nitrification-denitrification processes [16]. Ji et al. [8] used four different types of filter medium to treat wastewater with different ammonia levels: multimedia bio-ceramic, natural zeolite (diameter $>2 \mathrm{~mm}$ ), gravel (diameter $>10 \mathrm{~mm}$ ), and modified zeolite (diameter $>10 \mathrm{~mm}$ ). The multimedia biofilters reduced $88 \%$ of $\mathrm{NH}_{4}^{+}-\mathrm{N}$ and $88 \%$ of TN. Similar observation was made by Wang et al. [1], who found that the biofilter filled with polyurethane foaming plastic and porous lava rock reduced $96 \pm 2.1 \%$ of chemical oxygen demand (COD) and $87-98 \%$ of $\mathrm{NH}_{4}^{+}-\mathrm{N}$ throughout the phases of operation, and the filter medium adsorbed 22-31\% of $\mathrm{NH}_{4}^{+}-\mathrm{N}$ during the start-up stage. Zhang et al. [17] used an aerobic denitrification biofilter filled with reticulated polyurethane foam as the carrier material to remove nitrate $\left(\mathrm{NO}_{3}^{-}-\mathrm{N}\right)$ of groundwater. The $\mathrm{TN}$ and $\mathrm{NO}_{3}-\mathrm{N}$ removal efficiencies were $82.3-95.8 \%$ and 93.2-98.2\%, respectively. Based on the above research, it is evident that $\mathrm{NH}_{4}^{+}-\mathrm{N}$ adsorption by filter medium was the dominant mechanism in $\mathrm{NH}_{4}^{+}-\mathrm{N}$ removal during the start-up stage of biofilters because chemoautotrophic nitrifying bacteria are slow-growing and need more time to function well. During the operational period, biodegradation was the key mechanism responsible for removing nitrogen in biofilters.

Most laboratory studies of biofilter performance have reported quite good removal for $\mathrm{NH}_{4}^{+}-\mathrm{N}$ and $\mathrm{NO}_{3}^{-}-\mathrm{N}$. Wang et al. [7] investigated a biofilter (working volume of $144 \mathrm{~L}$ ) for improving drinking water. The influent concentration of COD, $\mathrm{NH}_{4}^{+}-\mathrm{N}, \mathrm{NO}_{3}-\mathrm{N}$, and temperature were $6.0-25.0 \mathrm{mg} / \mathrm{L}, 1.2-15 \mathrm{mg} / \mathrm{L}, 4.9-5.0 \mathrm{mg} / \mathrm{L}$, and $10.3-26.9^{\circ} \mathrm{C}$, respectively. The biofilter was operated at the hydraulic loading rate of $2.0 \mathrm{~m}^{3} /\left(\mathrm{m}^{2} \mathrm{~d}\right)$. They noted that $\mathrm{NH}_{4}^{+}-\mathrm{N}$ removal efficiencies ranged from $80.0 \%$ to $95.8 \%$. The $\mathrm{NO}_{3}^{-}-\mathrm{N}$ effluent concentration increased from 5.3 to $12.1 \mathrm{mg} / \mathrm{L}$ during operational periods, suggesting more research was needed to further enhance nitrogen removal and polish effluent. Hasan et al. [18] studied an aerated biofilter for drinking water treatment. When the 
Table 1. Biofilter traditional method for ammonium and nitrate remove from wastewater.

\begin{tabular}{|c|c|c|c|c|}
\hline Reactor & Carrier & Experiment condition & Removal efficiency & Reference \\
\hline $\begin{array}{l}\text { Denitrifying } \\
\text { biofilter }\end{array}$ & $\begin{array}{l}\text { Polycaprolacto- } \\
\text { ne }\end{array}$ & $\begin{array}{c}\mathrm{NO}_{3}^{-}-: \text {: } 17.6-33 \mathrm{mg} / \mathrm{L} \text {; HRT: } 0.2-0.8 \mathrm{~h} ; \\
\text { Temperature: } 17.5-24^{\circ} \mathrm{C} ;\end{array}$ & TN: $87.5-99.6 \%$ & {$[20]$} \\
\hline $\begin{array}{l}\text { Vertical flow } \\
\text { trickling filter }\end{array}$ & $\begin{array}{c}\text { Gravel and } \\
\text { zeolite }\end{array}$ & $\begin{array}{c}\mathrm{COD}: 98-417 \mathrm{mg} / \mathrm{L} ; \mathrm{TN}: 49-50 \mathrm{mg} / \mathrm{L} ; \\
\mathrm{NH}_{4}^{+}: 48.6-49.8 \mathrm{mg} / \mathrm{L} ; \mathrm{pH}: 6.6-7.0\end{array}$ & $\begin{array}{c}\text { COD : } 94.1 \% ; \mathrm{NH}_{4}^{+}: 96.1 \% \\
\text { TN: } 92.8 \%\end{array}$ & {$[21]$} \\
\hline $\begin{array}{l}\text { Lab-scale } \\
\text { multimedia } \\
\text { biofilter }\end{array}$ & $\begin{array}{l}\text { Polyurethane } \\
\text { foaming plastic, } \\
\text { lava rock }\end{array}$ & $\begin{array}{l}\text { COD: } 6.0-25.0 \mathrm{mg} / \mathrm{L} ; \mathrm{NH}_{4}^{+}: 1.2-15.0 \mathrm{mg} / \mathrm{L} \\
\text { Nitrogen loading rate: } 1.7-20.8 \mathrm{~g}-\mathrm{N} / \mathrm{m}^{2} \mathrm{~d} \\
\text { CLR: } 8.3-34.7 \mathrm{~g}-\mathrm{COD} / \mathrm{m}^{2} \mathrm{~d} .\end{array}$ & $\begin{array}{l}\mathrm{COD}: 76-96 \% \\
\mathrm{NH}_{4}^{+}: 76-98 \%\end{array}$ & [1] \\
\hline Biotrickling filter & $\begin{array}{l}\text { Light-weight } \\
\text { filtration media }\end{array}$ & $\begin{array}{l}\mathrm{NO}_{3}^{-}-\mathrm{N}: 4,50-5.50 \mathrm{mg} / \mathrm{L} ; \mathrm{NH}_{4}^{+}{ }^{+} \mathrm{N}: 0.01-0.3 \\
\mathrm{mg} / \mathrm{L} ; \mathrm{TN}: 4.85-6.23 \mathrm{mg} / \mathrm{L} ; \mathrm{DO}: 6.0-8.0 \mathrm{mg} / \mathrm{L}\end{array}$ & $\begin{array}{l}\mathrm{TN} \text { removal rate: } 3.5-10.2 \\
\mathrm{mg} / \mathrm{L} \cdot \mathrm{h} ; \mathrm{NO}_{3}^{-}-\mathrm{N} \text { removal } \\
\text { rate: } 3.2-10.2 \mathrm{mg} / \mathrm{L} \cdot \mathrm{h}\end{array}$ & [22] \\
\hline $\begin{array}{l}\text { Denitrification } \\
\text { biofilters }\end{array}$ & $\begin{array}{l}\text { Polyurethane } \\
\text { foam }\end{array}$ & $\mathrm{NO}_{3}^{-}-:=30-100 \mathrm{mg} / \mathrm{L} ; \mathrm{NH}_{4}^{+}: 15 \mathrm{mg} / \mathrm{L} ; \mathrm{pH}: 7.2$ & $\begin{array}{c}\text { TN: } 18.5-92.2 \% \\
\mathrm{NO}_{3}^{-}-: \text {: } 42.9-99.5 \% \\
\text { COD: } 50.5-93.7 \%\end{array}$ & [23] \\
\hline $\begin{array}{l}\text { Double-layer } \\
\text { biofilter }\end{array}$ & $\begin{array}{c}\text { Carbon-rich } \\
\text { ceramic granules }\end{array}$ & $\begin{array}{c}\text { COD: } 26-209 \mathrm{mg} / \mathrm{L} ; \mathrm{TN}: 6.9-38.3 \mathrm{mg} / \mathrm{L} ; \\
\mathrm{NH}_{4}^{+}: 2.2-35.8 \mathrm{mg} / \mathrm{L} ; \mathrm{pH}: 6.1-8.3\end{array}$ & $\begin{array}{l}\text { COD: } 82-91 \% ; \mathrm{NH}_{4}^{+}: \\
83-99 \% \text {; TN: } 50-60 \% \text {. }\end{array}$ & {$[24]$} \\
\hline $\begin{array}{l}\text { Multimedia } \\
\text { biofilters }\end{array}$ & $\begin{array}{l}\text { Pore mesh } \\
\text { material, } \\
\text { bio-ceramic, } \\
\text { natural zeolite }\end{array}$ & $\begin{array}{c}\mathrm{TN}: 2.5-121.8 \mathrm{mg} / \mathrm{L} ; \mathrm{NH}_{4}^{+}: 1.0-102.8 \mathrm{mg} / \mathrm{L} \\
\mathrm{NO}_{3}^{-}: 1.5-19.0 \mathrm{mg} / \mathrm{L} ; \mathrm{HL}: 31.2-125.0 \mathrm{~cm} / \mathrm{d} \\
\text { Temperature: } 18-25^{\circ} \mathrm{C}\end{array}$ & $\mathrm{NH}_{4}^{+}$and TN: $88 \%$. & [8] \\
\hline $\begin{array}{l}\text { Moving-bed } \\
\text { biofilm reactors }\end{array}$ & $\begin{array}{c}\text { Hacketten } \\
\text { carrier and } \\
\text { cylinder carrier }\end{array}$ & $\begin{array}{c}\text { DO: } 6.93-7.51 \mathrm{mg} / \mathrm{L} ; \mathrm{pH}: 7.27-7.52 ; \mathrm{COD}: \\
\quad 2.1 \mathrm{mg} / \mathrm{L} ; \mathrm{NH}_{4}^{++}: 0.65-2.18 \mathrm{mg} / \mathrm{L}\end{array}$ & $\mathrm{NH}_{4}^{+}: 63.1 \%$ & {$[25]$} \\
\hline $\begin{array}{l}\text { Subsurface } \\
\text { wastewater } \\
\text { filter systems }\end{array}$ & $\begin{array}{l}\text { Gravel, modified } \\
\text { zeolite }\end{array}$ & $\begin{array}{c}\mathrm{TN}: 12.5-53.4 \mathrm{mg} / \mathrm{L} ; \mathrm{NH}_{4}^{+}: 4.2-50.8 \mathrm{mg} / \mathrm{L} ; \\
\mathrm{NO}_{3}^{-}: 2.6-6.8 \mathrm{mg} / \mathrm{L} ; \mathrm{COD}: 22.6-165.2 \mathrm{mg} / \mathrm{L} \\
\text { HL: } 2.5-10.0 \mathrm{~cm} / \mathrm{d}\end{array}$ & $\begin{array}{l}\text { COD: } 57-99 \% ; \mathrm{NH}_{4}^{+}: \\
90-95 \% \text {; TN: } 65-90 \%\end{array}$ & {$[26]$} \\
\hline $\begin{array}{l}\text { Conventional } \\
\text { biofilters }\end{array}$ & $\begin{array}{l}\text { Volcanic rocks, } \\
\text { bioceramsite }\end{array}$ & COD:255.4-450 mg/L; pH: 6.6-8.4 & COD: $50-86 \%$ & {$[27]$} \\
\hline
\end{tabular}

COD: chemical oxygen demand; HLR: hydraulic loading rate; HL: hydraulic loading; CLR: COD loading rate;

HRT: hydraulic retention time

biofilter was operated with increasing organic loading rates $\left(0.2-1.0 \mathrm{~kg} \mathrm{COD} / \mathrm{m}^{3} \mathrm{~d}\right)$, aeration rates $(0-2 \mathrm{~L} / \mathrm{min})$, and hydraulic retention times $(6-24 \mathrm{~h})$, the average removal of $\mathrm{COD}$ and $\mathrm{NH}_{4}^{+}-\mathrm{N}$ increased to the range of $83.8-97.1 \%$ and $47.6-97.4 \%$, respectively. Shi et al. [19] studied the long-term performance of a pilot-scale denitrification biofilter (working volume of $91 \mathrm{~L}$ ) for the removal of $\mathrm{NO}_{3}^{-}-\mathrm{N}$. The influent concentration of $\mathrm{COD}$, $\mathrm{NO}_{3}-\mathrm{N}, \mathrm{pH}$, and dissolved oxygen (DO) were $20 \mathrm{mg} / \mathrm{L}$, $11.2 \mathrm{mg} / \mathrm{L}, 6.9 \mathrm{mg} / \mathrm{L}$, and $2.4 \mathrm{mg} / \mathrm{L}$, respectively. They found that the removal efficiencies of $\mathrm{NO}_{3}^{-}-\mathrm{N}$ ranged from $55 \%$ to $88 \%$. Ji et al. [10] studied an aerated multimedia biofilter with an effective volume of $9.6 \mathrm{~L}$ for synthetic wastewater treatment. The multimedia module media was filled with clinoptilolite and coal ash bioceramsite, and modified by metallic iron. The influent concentrations of $\mathrm{COD}, \mathrm{NH}_{4}^{+}-\mathrm{N}$, and total phosphorus were $100-400 \mathrm{mg} / \mathrm{L}, 20-40 \mathrm{mg} / \mathrm{L}$, and $4 \mathrm{mg} / \mathrm{L}$, respectively. They found that the removal efficiencies of COD and $\mathrm{NH}_{4}^{+}{ }^{+} \mathrm{N}$ were $81-94 \%$ and $82-95 \%$, respectively. A summary of the studies on traditional biofilters for nitrogen removal is shown in Table 1.

A review reveals that the biofilter technology is capable of treating inorganic nitrogen pollution in wastewater with COD content from 2.5 to $400 \mathrm{mg} / \mathrm{L}, \mathrm{NH}_{4}{ }^{+}-\mathrm{N}$ from 0.25 to $102.8 \mathrm{mg} / \mathrm{L}$, and $\mathrm{NO}_{3}-\mathrm{N}$ from 1.5 to $100 \mathrm{mg} / \mathrm{L}$. The biofilter used in those studies removed $37-99 \%$ of COD, $76-98 \%$ of $\mathrm{NH}_{4}^{+}-\mathrm{N}$, and TN $50-92 \%$ of TN. The pH in the biofilter systems ranged from 6.0 from 8.3 and the influents temperature varied between 10.3 and $26.9^{\circ} \mathrm{C}$. Thus, inorganic nitrogen pollution of wastewater having the above influent characteristics could be treated by biofilter systems.

\section{Newly Discovered Methods for Nitrogen Removal}

Newly discovered processes and technologies such as partial nitrification, anammox, simultaneous partial nitrification, anammox and denitrification (SNAD), single-reactor high activity ammonia removal over nitrite (SHARON), completely autotrophic nitrogen removal over nitrite (CANON), and oxygen-limited autotrophic nitrification-denitrification (OLAND) all have a high potential for nitrogen removal [16]. Guillén et al. [28] studied a partial nitrification biofilter for synthetic wastewater treatment. The biofilter removed the $31.7-76 \%$ of $\mathrm{NH}_{4}^{+}-\mathrm{N}$ and $52-54 \%$ of TN, respectively. Chatterjee et al. [29] developed an anammox biofilter with a working volume of $10 \mathrm{~L}$ for removing nitrogen from wastewater. 
Table 2. Biofilter new methods for ammonium and nitrate remove from wastewater.

\begin{tabular}{|c|c|c|c|c|}
\hline Reactor & Carrier & Experiment conditions & Removal efficiency & Reference \\
\hline $\begin{array}{l}\text { Anammox biofilm } \\
\text { reactor }\end{array}$ & Nylon ropes & $\begin{array}{c}\text { COD: } 36-48 \mathrm{mg} / \mathrm{L} ; \text { TN loading:0.07-0.20 kg TN } / \mathrm{m}^{3} \\
\mathrm{~d} \text {; CLR:0.053-0.176 kg COD } / \mathrm{m}^{3} \mathrm{~d} \text {; HRT: } 4.36-12 \mathrm{~h} ; \\
\text { Temperature: } 14-41^{\circ} \mathrm{C}\end{array}$ & $\begin{array}{l}\text { COD: } 78 \pm 2 \% \\
\mathrm{NH}_{4}^{+}: 95 \pm 1 \% \\
\text { TN: } 79 \pm 11 \%\end{array}$ & [29] \\
\hline $\begin{array}{l}\text { Anammox } \\
\text { trickling filter }\end{array}$ & $\begin{array}{l}\text { Polyurethane } \\
\text { sponge }\end{array}$ & $\begin{array}{c}\text { Temperature: } 30.5^{\circ} \mathrm{C} ; \mathrm{pH}: 7.89 ; \mathrm{NH}_{4}^{+}: 49-50 \mathrm{mg} / \mathrm{L} \\
\mathrm{NO}_{2}^{-}: 50-52 \mathrm{mg} / \mathrm{L} ; \mathrm{HRT}: 1.14-2.23 \mathrm{~h} ; \mathrm{HLR}: \\
3.4-13.7 \mathrm{~m}^{3} / \mathrm{m}^{-2} \mathrm{~d} \text {; Temperature: } 20-30^{\circ} \mathrm{C}\end{array}$ & TN: 74\%-84\%; & {$[35]$} \\
\hline $\begin{array}{l}\text { Partial nitritation } \\
\text { trickling filter }\end{array}$ & $\begin{array}{l}\text { Polyurethane } \\
\text { sponge }\end{array}$ & $\begin{array}{c}\text { Flow: } 5.7-14.9 \mathrm{~L} / \mathrm{d} ; \text { HRT: } 1.6-4.2 \mathrm{~h} \text {; HLR: } \\
\text { 1.3-3.3 } \mathrm{m}^{3} / \mathrm{m}^{2} \mathrm{~d} ; \\
\mathrm{NH}_{4}^{+}: 111.5-118.5 \mathrm{mg} / \mathrm{L}\end{array}$ & $\begin{array}{c}\mathrm{NH}_{4}^{+}: 31.7 \%-76 \% \\
\text { TN: } 52 \%-54 \%\end{array}$ & {$[28]$} \\
\hline SNAD biofilter & Volcanic rock & $\begin{array}{l}\mathrm{NH}_{4}^{+}: 200 \mathrm{mg} / \mathrm{L} \text {; Temperature: } 25^{\circ} \mathrm{C} \text {; Aeration rate: } \\
4.5 \mathrm{~L} / \mathrm{min} \text {; Influent } \mathrm{C} / \mathrm{N} \text { ratio: } 0.2 ; \mathrm{HRT}(\mathrm{h}): 0.55-0.6 \text {. }\end{array}$ & $\begin{array}{l}\text { TN: } 65 \%-76 \% \\
\text { COD: } 81 \%\end{array}$ & {$[30]$} \\
\hline Anammox biofilter & Volcanic rock & $\mathrm{NH}_{4}^{+}: 46.5 \mathrm{mg} / \mathrm{L}$; Temperature: $15.3-23.2^{\circ} \mathrm{C}$. & TN: $76 \%$. & {$[31]$} \\
\hline CANON biofilter & $\begin{array}{l}\text { Volcanic } \\
\text { rock }\end{array}$ & $\begin{array}{c}\mathrm{NH}_{4}^{+}: 100-400 \mathrm{mg} / \mathrm{L} ; \text { HRT }(\mathrm{h}): 0.52-11.70 ; \mathrm{pH}: 7.87- \\
\text { 8.20. Temperature: } 24.3-27.6^{\circ} \mathrm{C} \\
\text { DO: } 5.06-6.72 \mathrm{mg} / \mathrm{L}\end{array}$ & TN: $61 \%-67 \%$. & {$[32]$} \\
\hline SHARON biofilter & PVC & $\begin{array}{l}\text { Oxygen demand: } 1.5 \mathrm{mg} / \mathrm{L} ; \mathrm{pH}: 7.5 \text {; Temperature: } \\
35^{\circ} \mathrm{C} \text {; HRT: } 0.4-0.5 \text { day; } \mathrm{NH}_{4}^{+}: 600 \mathrm{mg} / \mathrm{L} \text {. }\end{array}$ & $\mathrm{NH}_{4}^{+}: 60-100 \%$ & [33] \\
\hline OLAND biofilter & $\begin{array}{l}\text { Polyvinylchl- } \\
\text { oride }\end{array}$ & $\begin{array}{l}\text { HRT }(\mathrm{d}): 0.77-0.91 ; \mathrm{NH}_{4}^{+}: 476-846 \mathrm{mg} / \mathrm{L} ; \\
\quad \text { Loading rate: } 525-1100 \mathrm{mg} \mathrm{N} / \mathrm{L} \mathrm{d} .\end{array}$ & TN: $84 \%$. & {$[34]$} \\
\hline
\end{tabular}

COD: chemical oxygen demand; HLR: hydraulic loading rate; CLR: COD loading rate; HRT: hydraulic retention time

The biofilter removed the $78 \pm 2 \%$ of COD, $95 \pm 1 \%$ of $\mathrm{NH}_{4}^{+}-\mathrm{N}$, and $79 \pm 11 \%$ of TN. Liang et al. [30] investigated a 40 L SNAD biofilter filled with volcanic rock as biofilm carrier for treating low $\mathrm{C} / \mathrm{N}$ ratio synthetic wastewater. The results suggested that the biofilter simultaneously removed $70.5 \%$ of TN and $81 \%$ of COD. Zeng et al. [31] developed an upflow anammox biofilter for treating synthetic wastewater with low ammonia concentration $(46.5 \mathrm{mg} / \mathrm{L})$ at ambient temperature $\left(15.3-23.2^{\circ} \mathrm{C}\right)$, and the average nitrogen removal rate and removal efficiency were $2.26 \mathrm{~kg} / \mathrm{m}^{3}$ day) and $75.9 \%$, respectively.

Liang et al. [32] used a CANON biofilter (working volume: $40 \mathrm{~L}$ ) packed with volcanic rock as biofilm carrier for treating different ammonia levels in wastewater. The influent of $\mathrm{NH}_{4}^{+}-\mathrm{N}, \mathrm{DO}$, and $\mathrm{pH}$ were $100-800 \mathrm{mg} / \mathrm{L}$, $5.06-6.72 \mathrm{mg} / \mathrm{L}$, and $7.87-8.20$. The maximum nitrogen removal rate ranged from 0.5 to $3.7 \mathrm{~kg} /\left(\mathrm{m}^{3} \mathrm{~d}\right)$. They found that the removal efficiencies of $\mathrm{NH}_{4}^{+}-\mathrm{N}$ were $55-85 \%$. González-Martínez et al. [33] constructed a submerged SHARON biofilter (working volume: $3 \mathrm{~L}$ ) with PVC carriers for treating high concentrations of $\mathrm{NH}_{4}^{+}-\mathrm{N}$ and low COD wastewater. The influent of $\mathrm{NH}_{4}^{+}-\mathrm{N}, \mathrm{DO}$, and $\mathrm{pH}$ temperature were $600 \mathrm{mg} / \mathrm{L}, 1.5 \mathrm{mg} / \mathrm{L}, 7.5$, and $35^{\circ} \mathrm{C}$. They found that the removal efficiencies of $\mathrm{NH}_{4}^{+}-\mathrm{N}$ were $100 \%$ at a hydraulic retention time (HRT) of 0.5 day and $65 \%$ at a HRT of 0.4 day. Windey et al. [34] constructed a biological contact reactor (working volume: $50 \mathrm{~L}$ ) operated under OLAND conditions treating high-salinity wastewater. The influent of $\mathrm{NH}_{4}^{+}-\mathrm{N}$ was $476-846 \mathrm{mg} / \mathrm{L}$, and the HRT was 0.77-0.91 day. They found that the removal efficiencies of $\mathrm{NH}_{4}^{+}-\mathrm{N}$ and TN were $70 \%$ and $57 \%-93 \%$, respectively. The OLAND process consumes $63 \%$ less oxygen and $100 \%$ less biodegradable organic carbon compared to the conventional nitrification-denitrification process and has, therefore, a lower operating cost. A summary of the studies on novel biofilters for nitrogen removal is shown in Table 2.

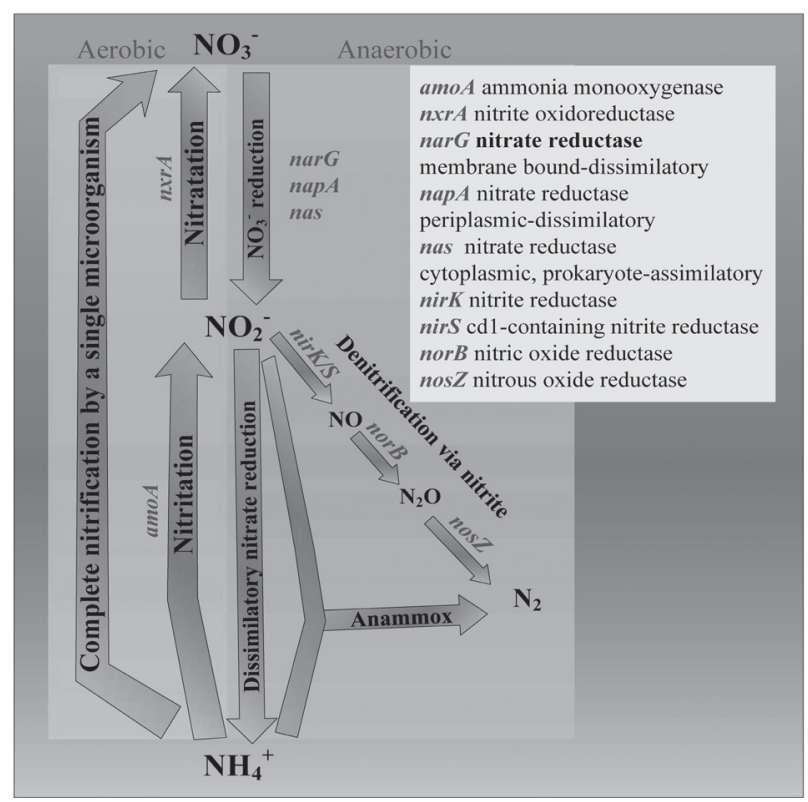

Fig. 1. The major biological nitrogen transformation pathways in biofilters are linked by their associated enzymes [adapted from 37]. Genes encoding enzymes that conduct the important transformations include those for various nitrate reductases (nas, narG, napA), nitrite reductases (nirK/S), nitric oxide reductase (nor $B$ ), nitrous oxide reductase (nosZ), ammonium monooxygenase (amoA), nitrite oxidoreductase (nxrA), and anaerobic ammonium oxidation (anammox). 
A review of these novel biofilter systems reveals that the biofilter technology is capable of treating specific wastewater (i.e., low $\mathrm{C} / \mathrm{N}$ ratio, high $\mathrm{NH}_{4}^{+}-\mathrm{N}$ ) or reducing operational cost. Research focusing on the CANON biofilters is intense at present due to its several advantages, including less aeration demand, no organic carbon consumption, and less sludge production. The SNAD biofilter can be used for treating low $\mathrm{C} / \mathrm{N}$ ratio sewage due to its high TN removal efficiency. The SHARON biofilter can be used for treating high concentrations of $\mathrm{NH}_{4}^{+}-\mathrm{N}$ and low of COD wastewater. The OLAND and partial nitrification biofilter is a feasible alternative for treating highly $\mathrm{NH}_{4}^{+}$-N-loaded wastewater.

\section{Nitrogen Removal Process}

The main biodegradation processes in a biofilter includes nitrification, denitrification, anammox, dissimilatory/assimilatory nitrate reduction to ammonium, and complete oxidation of ammonia to nitrate in one organism (comammox) (Fig. 1) [7-8, 36]. Fortunately, with the discovery of the anammox pathway, new nitrogen removal techniques using biofilter systems have opened up. This section reviews what is known about biological nitrogen transformation pathways in biofilters.

\section{Nitrification Process}

Nitrification is a predominant microbiological process in which $\mathrm{NH}_{4}^{+}-\mathrm{N}$ is converted to $\mathrm{NO}_{3}^{-}-\mathrm{N}$ under aerobic environmental conditions in biofilters (Table 3 ).
Autotrophic nitrification is a two-step aerobic process in which $\mathrm{NH}_{4}^{+}-\mathrm{N}$ is oxidized to $\mathrm{NO}_{2}^{-}-\mathrm{N}$ by ammoniumoxidizing bacteria ( $A O B$, Nitroso-) and $\mathrm{NO}_{3}^{-}-\mathrm{N}$ by nitriteoxidizing bacteria (NOB, Nitro-) [38]. Nitrosomonas europea, Nitrosomonas mobilis strains, Nitrosomonas eutropha, and Nitrosomonas nitrosa were considered the main microorganisms in ammonium oxidation. Nitrobacter spp. and Nitrospira spp. were considered the predominant players in nitrite oxidation in biofilters [39]. Detection of nitrification bacteria in biofilters has generally targeted amo $A$ and $n x r A$ genes $[8,37]$. The amo $A$ gene has been utilized as a molecular marker for quantitative studies of $A O B$ and archaea $(A O A)$ in biofilters [40]. The nitrite oxidase coding gene $n x r A$ has been utilized as a marker of $\mathrm{NO}_{2}^{-}-\mathrm{N}$ oxidation [41]. Wang et al. [1] reported that the functional roles of $A O B, A O A$, and $N O B$ have been analyzed by building quantitative relationships between $\mathrm{NH}_{4}^{+}-\mathrm{N}$ and $\mathrm{NO}_{2}^{-}-\mathrm{N}$ transformation rates and functional genes in a multimedia biofilter. The results revealed that amoA/archaea had the prominent contribution on the $\mathrm{NH}_{4}^{+}-\mathrm{N}$ removal rate $(54.6 \%)$. Bagchi et al. [42] investigated the decrease of $\mathrm{NH}_{4}^{+}-\mathrm{N}$ accumulation in nitrifying biofilters by enhancing rapid conversion to $\mathrm{NO}_{3}^{-}-\mathrm{N}$ via $\mathrm{NO}_{2}^{-}-\mathrm{N}$. Nitrogen balances analysis suggested that active nitrification accounted for $\geq 81-86 \%$ of $\mathrm{TN}$ conversion.

The nitrification process was determined to be a pivotal pathway responsible for the robust $\mathrm{NH}_{4}^{+}-\mathrm{N}$ treatment performance in biofilters. The primary factors in controlling nitrification process include free ammonia, temperature, dissolved oxygen (DO), and $\mathrm{pH}$. Free

Table 3. Simplified equations for selected microbial nitrogen transformation processes [16, 43].

\begin{tabular}{|c|c|c|}
\hline No. & Process & Biochemical conversion \\
\hline 1 & Nitritification & $\mathrm{NH}_{4}^{+}+1.5 \mathrm{O}_{2}+2 \mathrm{HCO}_{3}^{-} \rightarrow \mathrm{NO}_{2}^{-}+2 \mathrm{CO}_{2}+3 \mathrm{H}_{2} \mathrm{O}$ \\
\hline 2 & Nitratation & $\mathrm{NO}_{2}^{-}+0.5 \mathrm{O}_{2} \rightarrow \mathrm{NO}_{3}^{-}$ \\
\hline $1+2$ & Nitrification & $\mathrm{NH}_{4}^{+}+2 \mathrm{O}_{2}+2 \mathrm{HCO}_{3}^{-} \rightarrow \mathrm{NO}_{3}^{-}+2 \mathrm{CO}_{2}+3 \mathrm{H}_{2} \mathrm{O}$ \\
\hline 3 & Denitratation & $2 \mathrm{NO}_{3}^{-}+\mathrm{C} \rightarrow 2 \mathrm{NO}_{2}^{-}+\mathrm{CO}_{2}$ \\
\hline 4 & $\begin{array}{l}\text { Denitrification via nitrite } \\
\text { (Denitritification) }\end{array}$ & $4 \mathrm{NO}_{2}^{-}+3 \mathrm{C}+2 \mathrm{H}_{2} \mathrm{O}+\mathrm{CO}_{2} \rightarrow 2 \mathrm{~N}_{2}+4 \mathrm{HCO}_{3}^{-}$ \\
\hline $3+4$ & Denitrification & $4 \mathrm{NO}_{3}^{-}+5 \mathrm{C}+2 \mathrm{H}_{2} \mathrm{O} \rightarrow 2 \mathrm{~N}_{2}+4 \mathrm{HCO}_{3}^{-}+\mathrm{CO}_{2}$ \\
\hline 5 & Partial nitrification ( $50 \%$ conversion $)$ & $\mathrm{NH}_{4}^{+}+0.75 \mathrm{O}_{2}+\mathrm{HCO}_{3}^{-} \rightarrow 0.5 \mathrm{NO}_{2}^{-}+0.5 \mathrm{NH}_{4}^{+}+\mathrm{CO}_{2}+1.5 \mathrm{H}_{2} \mathrm{O}$ \\
\hline $6 \mathrm{a}$ & Anammox (without cell synthesis) & $\mathrm{NH}_{4}^{+}+\mathrm{NO}_{2}^{-} \rightarrow \mathrm{N}_{2}+2 \mathrm{H}_{2} \mathrm{O}$ \\
\hline $6 b$ & Anammox (with cell synthesis) & $\begin{array}{c}\mathrm{NH}_{4}^{+}+1.32 \mathrm{NO}_{2}^{-}+0.066 \mathrm{HCO}_{3}^{-} \rightarrow 1.02 \mathrm{~N}_{2}+0.26 \mathrm{NO}_{3}^{-}+0.66 \\
\mathrm{CH}_{2} \mathrm{O}_{0.5} \mathrm{~N}_{0.15}+2.03 \mathrm{H}_{2} \mathrm{O}\end{array}$ \\
\hline $1+2+3+4$ & Traditional nitrification denitrification & $\mathrm{NH}_{4}^{+}+8 \mathrm{O}_{2}+5 \mathrm{C}+4 \mathrm{HCO}_{3}^{-} \rightarrow 2 \mathrm{~N}_{2}+9 \mathrm{CO}_{2}+10 \mathrm{H}_{2} \mathrm{O}$ \\
\hline $3+5+6$ & SNAD & - \\
\hline $1+6$ & CANON & $\mathrm{NH}_{3}+0.85 \mathrm{O}_{2} \rightarrow 0.11 \mathrm{NO}_{3}^{-}+0.44 \mathrm{~N}_{2}+0.14 \mathrm{H}^{+}+1.43 \mathrm{H}_{2} \mathrm{O}$ \\
\hline 7 & OLAND & $\mathrm{NH}_{4}^{+}+0.75 \mathrm{O}_{2} \rightarrow 0.5 \mathrm{~N}_{2}+\mathrm{H}^{+}+1.5 \mathrm{H}_{2} \mathrm{O}$ \\
\hline 8 & SHARON & $\mathrm{NH}_{4}^{+}+\mathrm{HCO}_{3}^{-}+0.75 \mathrm{O}_{2} \rightarrow 0.5 \mathrm{NH}_{4}^{+}+0.5 \mathrm{NO}_{2}^{-}+\mathrm{CO}_{2}+1.5 \mathrm{H}_{2} \mathrm{O}$ \\
\hline 9 & Complete ammonia oxidation & $\mathrm{NH}_{4}^{+}+2 \mathrm{O}_{2} \rightarrow \mathrm{NO}_{3}^{-}+\mathrm{H}_{2} \mathrm{O}+2 \mathrm{H}^{+}$ \\
\hline
\end{tabular}


ammonia has a great influence on $A O B$ and $N O B$. $N O B$ are more sensitive than the $A O B$ to free ammonia at high $\mathrm{pH}$ of 7.5-8. The inhibition of aerobic ammonia oxidizers and nitrite oxidation in aquatic environments is observed at $\mathrm{NH}_{3}-\mathrm{N}$ concentrations of $10-150 \mathrm{mg} / \mathrm{L}$ and 0.08-0.82 $\mathrm{mg} / \mathrm{L}$ [44]. However, Kim et al. [45] reported that Nitrobacter spp. and Nitrospira spp. were inhibited at 30 50 mg $\mathrm{NH}_{3}-\mathrm{N} / \mathrm{L}$ and $0.04 \sim 0.08 \mathrm{mg}$ $\mathrm{NH}_{3}-\mathrm{N} / \mathrm{L}$, respectively, suggesting a different threshold for Nitrobacter spp. and Nitrospira spp. Another study by Vadivelu et al. [46] reported that 100\% inhibition of Nitrobacter sp. anabolism and 12-25\% inhibition of Nitrobacter sp. catabolism were observed at $\mathrm{NH}_{3}-\mathrm{N}$ concentrations of 1-9 mg/L.

Temperature has a strong influence on nitrifying activity. Nitrifying activity would be limited at less than $8-10^{\circ} \mathrm{C}$ or higher than $35-45^{\circ} \mathrm{C}$, and the maximum growth rate of $A O B$ and $N O B$ are observed at $35^{\circ} \mathrm{C}$, and the thermal death points of Nitrosomonas spp. are observed at $54-58^{\circ} \mathrm{C}$ [47-48]. The DO concentration is very important for both $A O B$ and $N O B$. Kim et al. [49] reported that low ammonium conversion and low $\mathrm{NO}_{2}^{-}-\mathrm{N}$ and $\mathrm{NO}_{3}^{-}-\mathrm{N}$ accumulation are observed at DO less than
$1.0 \mathrm{mg} / \mathrm{L}$. Garrido et al. [50] reported that stable and 100\% nitrite accumulation was observed at DO of $1.0 \mathrm{mg} / \mathrm{L}$, and $50 \%$ of ammonium conversion to nitrite could also be obtained at DO of $1.5 \mathrm{mg} / \mathrm{L}$. Full nitrification could also be obtained at DO higher $2.5 \mathrm{mg} / \mathrm{L}$, and $\mathrm{NH}_{4}^{+}-\mathrm{N}$ removal depended on applied ammonium load. The nitrite oxidizers are more sensitive to oxygen limitation than that of ammonium oxidizers [44]. Euiso et al. [47] also reported that the inhibition of ammonium and nitrite oxidizers was observed at temperature higher than $35-45^{\circ} \mathrm{C}$ or lower than $8-10^{\circ} \mathrm{C}$. The $\mathrm{pH}$ of influent water showed significant impact on nitrifying bacteria activity. An optimum range of $\mathrm{pH}$ for ammonia oxidizers (Nitrosomonas spp.) and nitrite oxidizers (Nitrobacter spp.) were 7.9-8.2 and 7.2-7.6, respectively [51]. The 100\% inhibition of $N O B$ activity was observed at $\mathrm{pH}$ less than 6.5 [52]. The specific growth rate of ammonium oxidizers and nitrite oxidizers decreased as the $\mathrm{pH}$ increases up 9-9.5 [53]. Effects of free ammonia, temperature, dissolved oxygen, and $\mathrm{pH}$ on the nitrification process are shown in Table 4.

A review of nitrification reveals that a number of environmental factors influence nitrogen removal in

Table 4. Effects of free ammonia, temperature, $\mathrm{pH}$, and $\mathrm{DO}$ on the nitrification process.

\begin{tabular}{|c|c|c|}
\hline Factor & Effect & References \\
\hline \multicolumn{3}{|c|}{ Free $\mathrm{NH}_{3}-\mathrm{N}(\mathrm{mg} / \mathrm{L})$} \\
\hline $10-150$ & Inhibition of ammonium oxidizers & [44] \\
\hline $30-50$ & Inhibition of Nitrobacter spp. & [45] \\
\hline $0.08-0.82$ & Inhibition of nitrite oxidizers & [44] \\
\hline $0.04-0.8$ & Inhibition of Nitrospira spp. & {$[45]$} \\
\hline $1-9$ & $100 \%$ inhibition of Nitrobacter sp. anabolism, and $12-25 \%$ inhibition of Nitrobacter sp. catabolism & [46] \\
\hline \multicolumn{3}{|c|}{ Temperature $\left(T,{ }^{\circ}\right)$} \\
\hline$<(8-10)$ & Inhibition of ammonium and nitrite oxidizers & {$[47]$} \\
\hline$=25$ & Ammonium oxidizers can out-compete nitrite oxidizers & [43] \\
\hline$=35$ & Maximum Growth rate of AOBs and NOBs & {$[54]$} \\
\hline$>(35-45)$ & Inhibition of ammonium and nitrite oxidizers & {$[48]$} \\
\hline \multicolumn{3}{|c|}{$\mathrm{DO}(\mathrm{mg} / \mathrm{L})$} \\
\hline$<1.0$ & Low ammonium conversion and low $\mathrm{NO}_{2}^{-}$and $\mathrm{NO}_{3}^{-}$accumulation & [49] \\
\hline$=1.0$ & Stable and $100 \%$ nitrite accumulation & {$[50]$} \\
\hline 1.5 & $50 \%$ of ammonium conversion to nitrite & {$[50]$} \\
\hline$>2.5$ & Full nitrification, $\mathrm{NH}_{4}^{+}-\mathrm{N}$ oxidation depended on applied ammonium load & {$[50]$} \\
\hline $2.0-5.0$ & Nitrite accumulation up to $60 \%$ of total ammonia conversion & {$[55]$} \\
\hline \multicolumn{3}{|c|}{$\mathrm{pH}$} \\
\hline$<6.5$ & Complete inhibition of the NOBs activity & {$[52]$} \\
\hline 7.9-8.2 & Optimum range for ammonia oxidizers (Nitrosomonas spp.) & {$[53]$} \\
\hline 7.2-7.6 & Optimum range for nitrite oxidizers (Nitrobacter spp.) & {$[53]$} \\
\hline $9-9.5$ & Inhibition of ammonium and nitrite oxidizers & {$[53]$} \\
\hline
\end{tabular}


biofilters. In practice, all of the environmental factors have different effects on the growth rate and enrichment of ammonium and nitrite oxidizers. However, the nitrification process may also be influenced by several inhibitory compounds, including heavy metals, salinity, and alkalinity, as well as sludge age [56-58]. This study therefore highlights the need for more research efforts to study the importance of inhibitory compounds in nitrogen removal in biofilters. For a long time, bacterial nitrifiers were believed to be the only significant mechanism of autotrophic nitrification. It has been proved that Archaea played an important role in aerobic nitrification. Archaeal ammonium-oxidizer amo $A$ sequences have been identified in a laboratory-scale reactor [59]. Wang et al. [1] investigated the dynamic populations of Archaea in a lab-scale multimedia biofilter. The results suggested that Archaeal showed a much lower abundance (relative to bacteria). This study therefore highlights the need for more research efforts to study the importance of Archaeal in nitrogen removal in biofilters.

\section{Denitrification Process}

Denitrification is a sequential reduction process of $\mathrm{NO}_{3}{ }^{-}-\mathrm{N}$ to $\mathrm{N}_{2}$ (Table 3) [37]. The phylum proteobacteria, such as Alcaligenes, Azospirillum, Magnetospirillum, Bradyrhizobium, Rhizobia, and Azoarcus are assumed to be the key players in denitrification communities [60]. Different denitrification microbiotas played predominant roles during different processes and functioned with various activities in the presence of environmental changes [61-62]. Most denitrifying bacteria grow rapidly under anaerobic conditions, and they utilize organic compounds as electron donors in the denitrification process [63]. The six functional genes, including the membraneboundnitrate reductase gene (narG), periplasmic nitrate reductase gene (napA), $\mathrm{Cu}$-containing nitrite reductase gene (nirK), cytochromecd1- containing nitrite reductase gene (nir $S$ ), nitric oxide reductase gene (nor $B$ ), and nitrous oxide reductase gene (nos $Z$ ), have been used as molecular markers to study preferable denitrification processes [37, 62]. Zhang et al. [17] reported that the remarkable decrease in $\mathrm{NO}_{3}^{-}-\mathrm{N}$ monitored in a biofilter manifests that denitrification is an important microbiological process, and denitrification was estimated to account for $90 \%$ of $\mathrm{TN}$ removal and $95 \%$ of $\mathrm{NO}_{3}^{-}-\mathrm{N}$ removal. The ratio of norB/nos $Z$ served as the predominant driver for the transformation rates of $\mathrm{NO}_{3}^{-}-\mathrm{N}$ and $\mathrm{NH}_{4}^{+}-\mathrm{N}$, while the norB/nos $Z$ ratio followed by the ratio of (nir $S+$ nirK $) /$ nos $Z$ predominated a notable role in the accumulation of $\mathrm{N}_{2} \mathrm{O}$ and $\mathrm{NO}$ in the biofilter [17].

A number of studies have identified the key factors (i.e., temperature, $\mathrm{pH}, \mathrm{DO}$ ) governing denitrification in an attempt to achieve a satisfactory $\mathrm{NO}_{3}^{-}-\mathrm{N}$ removal. The denitrification microbial growth rate and the rate of biologically mediated reactions generally increase exponentially with increasing temperature. Denitrification activity would be limited below $20^{\circ} \mathrm{C}$ or above $60-75^{\circ} \mathrm{C}$ [64]. The $\mathrm{pH}$ of influent water has a strong influence on denitrifier activity. An optimum range of $\mathrm{pH}$ for denitrification rate is 7.0-7.5, and $\mathrm{pH}$ values below 4 and above 10 caused the almost complete inhibition of the denitrification rate [65]. The significant inhibition of denitrification activity was observed at $\mathrm{pH}$ of 6.5-7, and high nitrite accumulation was shown at $\mathrm{pH}$ 7.5-9 [66]. Another study carried out by Zhang et al. [17] showed $\mathrm{NO}_{3}^{-}-\mathrm{N}$ transformation rates ranging from 21.0 to $23.4^{-} \mathrm{g} /\left(\mathrm{m}^{3} \mathrm{~h}\right)$, whereas $\mathrm{NO}_{2}^{-} \mathrm{N}$ and $\mathrm{NH}_{4}^{+}-\mathrm{N}$ transformation rates stabilized less than $6.0 \mathrm{~g} /\left(\mathrm{m}^{3} \mathrm{~h}\right)$ as the DO level increased from 1.0 to $6.0 \mathrm{mg} / \mathrm{L}$. Based on these observations, the growth rate and denitrification activity could vary due to the different responses of denitrification microorganisms to environmental factors.

\section{Anammox Process}

Under anaerobic conditions, $\mathrm{NH}_{4}^{+}-\mathrm{N}$ and $\mathrm{NO}_{2}^{-}-\mathrm{N}$ could be transformed into $\mathrm{N}_{2}$ through the anammox process (Table 3) [67]. Candidatus Brocadia, Candidatus Kuenenia, Candidatus Jettenia asiatica, and Candidatus Brocadia anammoxidans are assumed to be key players in the anammox process, and the anammox sequences have been identified [68]. The process of anammox is one of the most innovative technological advances in the removal of $\mathrm{NH}_{4}^{+}-\mathrm{N}$ from wastewater. Because of its high efficiency in nitrogen removal, anammox has been widely researched. Zeng et al. [31] investigated nitrogen removal efficiency and microbial community in treating low-strength wastewater using an anammox biofilter at ambient temperature $\left(15.3-23.2^{\circ} \mathrm{C}\right)$. The results revealed that microbial community structures varied with the decrease of influent $\mathrm{NH}_{4}^{+}-\mathrm{N}$ concentration, and the genus of functional anammox bacteria was Candidatus Kuenenia stuttgartiensis. Wang et al. [2] reported that the $\mathrm{NH}_{4}^{+}-\mathrm{N}$ removal efficiencies ranged from $67.3 \%$ to $92.7 \%$ under hydraulic loading rate $\left(1.0-3.0 \mathrm{~m}^{3} /\left(\mathrm{m}^{2} \mathrm{~d}\right)\right)$ constraints. The result indicated that the abundance of anammox bacteria was 100-1,000 times greater than that of amoA, suggesting that anammox was the predominant removal pathway of $\mathrm{NH}_{4}^{+}-\mathrm{N}$ in the biofilter.

The key environmental factors that influence anammox include $\mathrm{NH}_{3}-\mathrm{N}$, temperature, and $\mathrm{pH}$. Fernández et al. [69] reported that $50 \%$ and $80 \%$ inhibition of anammox activity in short-term tests (0-140 days) were observed

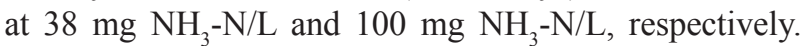
Tang et al. [70] observed that high $\mathrm{NH}_{3}-\mathrm{N}$ concentrations $(57-187 \mathrm{mg} / \mathrm{L})$ may be toxic to anammox microorganisms. However, Aktan et al. [71] reported that no inhibition of anammox activity was observed at $\mathrm{NH}_{3}-\mathrm{N}$ concentrations below $150 \mathrm{mg} / \mathrm{L}$, and the activity of anammox rapidly dropped to $10 \%$ when the $\mathrm{NH}_{3}-\mathrm{N}$ concentration reached $190 \mathrm{mg} / \mathrm{L}\left(\mathrm{T}=34^{\circ} \mathrm{C}\right.$ and $\left.\mathrm{pH}=8\right)$. Another study carried out by Aktan et al. [71] found the removal efficiency and elimination capacity of laboratory-scale biofilters (81 reactor volume) significantly decreased as the inlet $\mathrm{NH}_{3}-\mathrm{N}$ concentration increased to above $110 \mathrm{mg} / \mathrm{m}^{3}$. Previous studies showed that the appropriate temperature for anammox was about $30-40^{\circ} \mathrm{C}$ [72-73]. It is still 
a challenge for the anammox process to function well at low temperatures. The optimum range of $\mathrm{pH}$ for the process was 6.7-8.3 [12].

\section{Dissimilatory/Assimilatory Nitrate Reduction to Ammonium}

Dissimilatory nitrate reduction to ammonium (DNRA) and assimilatory nitrate reduction to ammonium (ANRA) are two notable processes involved with $\mathrm{NO}_{3}^{-}$reduction and the increase (accumulation) of $\mathrm{NH}_{4}^{+}-\mathrm{N}$ (Table 3) [37]. DNRA and ANRA could also occur, but the anaerobic environments in biofilter systems have high concentrations of $\mathrm{NH}_{4}^{+}-\mathrm{N}$ and organic $\mathrm{N}$, which repress this process or make it quantitatively insignificant [60]. In the absence of oxygen, $\mathrm{NO}_{3}^{-}-\mathrm{N}$ can be utilized by many microbes as a respiratory electron acceptor. $\mathrm{NO}_{3}^{-}-\mathrm{N}$ reduction is coupled to the anaerobic oxidation of organic carbon, producing either $\mathrm{NH}_{4}^{+}-\mathrm{N}$ or $\mathrm{N}_{2}$ gas during denitrification [37]. The $\mathrm{NO}_{3}^{-}-\mathrm{N}$ reduction coding gene nas is often used as a molecular marker for the ANRA process [37]. Wang et al. [7] investigated the absolute abundance and distribution pattern of nas gene in a biofilter. The results indicated that nas had a high direct negative contribution (-0.802) to $\mathrm{NH}_{4}^{+}-\mathrm{N}$ removal rate and a remarkable direct negative contribution (-0.806) to $\mathrm{NO}_{3}^{-}-\mathrm{N}$ accumulation.

\section{Complete Oxidation of Ammonia to Nitrate in One Organism (Comammox)}

Nitrification is a extensively accepted characteristic of the nitrogen cycle [37]. A newly nitrogen removal process, comammox, was first discovered in a recirculation aquaculture system biofilter [36]. Van Kessel et al. [36] reported the enrichment and initial characterization of two Nitrospira species that encode all the enzymes necessary for $\mathrm{NH}_{4}^{+}-\mathrm{N}$ oxidation via $\mathrm{NO}_{2}^{-}-\mathrm{N}$ to $\mathrm{NO}_{3}^{-}-\mathrm{N}$ in their genomes, and indeed completely oxidize ammonium to $\mathrm{NO}_{3}^{-}-\mathrm{N}$ to conserve energy. The findings of the comammox process will lead to a new recognition of the environmental abundance and distribution of ammoniaoxidizing microorganisms.

\section{Simultaneous Partial Nitrification, Anammox, and Denitrification (SNAD)}

SNAD comprises three main processes: partial nitrification (micro-aerobic), anammox (anoxic), and denitrification (anoxic) (Table 3). The anammox reaction is derived by a cluster of planctomycete bacteria, which always prefer to utilize $\mathrm{NO}_{2}^{-}-\mathrm{N}$ as electron acceptors [43]. Anammox prefers to be associated with partial nitrification, which can supply $\mathrm{NO}_{2}^{-}-\mathrm{N}$ substrate to the anammox process [74]QD Ru. The first step of the denitrification process $\left(\mathrm{NO}_{3}^{-}-\mathrm{N} \rightarrow \mathrm{NO}_{2}^{-}-\mathrm{N}\right)$, catalyzed by nar $G$ and nap $A$ codase under aerobic conditions, provided $\mathrm{NO}_{2}^{-}-\mathrm{N}$ substrate for the anammox process. Due to the slow growth rate of anammox, long start-up time is needed for anammox to function well in biofilters [1]. Liang et al. [30] investigated a 2.65 L SNAD biofilter for treating synthetic wastewater with high $\mathrm{NH}_{4}^{+}-\mathrm{N}$ and low organic carbon content. The influent ammonia, aeration rate, and temperature were $200 \mathrm{mg} / \mathrm{L}, 4.5 \mathrm{~L} / \mathrm{min}$, and $25^{\circ} \mathrm{C}$. The nitrogen removal rate and TN removal efficiency were $3.26 \mathrm{~kg} /\left(\mathrm{m}^{3} \mathrm{~d}\right)$, 65\%-76\%, respectively. Nitrosomonas and Candidatus brocadia were considered the predominant players in the biofilter. As noted by Wang et al. [62], SNAD were coupled at the molecular level (functional genes), and collaboratively contributed to $\mathrm{NH}_{4}^{+}-\mathrm{N}$ removal. The coexistence of the SNAD processes was the primary mechanism response to the simultaneous and robust performance of $\mathrm{NH}_{4}^{+}-\mathrm{N}$ and organic carbon treatment.

\section{Single Reactor High Activity Ammonia Removal over Nitrite (SHARON)}

The SHARON process is developed and applied for the treatment of high $\mathrm{NH}_{4}^{+}-\mathrm{N}$ wastewater by means of nitritation (Table 3) [75]. Due to the distinct responses to an increase of temperature, the $A O B$ grow faster than $N O B$ at temperatures above $20-35^{\circ} \mathrm{C}$. The SHARON process especially utilizes the high temperature to enhance the specific growth rates of $A O B$, suggesting no sludge production. Thus temperature could be used as a controlling operational parameter to achieve a SHARON process in biofilters. Previous studies indicated that temperature, $\mathrm{pH}$, and HRT are the three important process parameters for SHARON treating domestic sewage. Ammonium oxidizers have the corresponding maximum specific growth rate with a working temperature of $35^{\circ} \mathrm{C}$. A high $\mathrm{pH}(8.1-8.5)$ is preferable to outcompete nitrite oxidizers and obtain a lower effluent $\mathrm{NH}_{4}^{+}-\mathrm{N}$ concentration. González-Martínez et al. [33] constructed a partial-SHARON biofilter and investigated the influence of the HRT on nitrification process of the biofilter. An HRT of 0.5 day could decrease the bacterial biodiversity in the biofilms constituted by Nitrosomonas and Diaphorobacter. HRTs of 0.4 and 0.5 days could enhance the formation of biofilms constituted by Nitrosomonas sp., Nitrosospira sp., and Nitrosovibrio sp.

\section{Completely Autotrophic Nitrogen Removal over Nitrite (CANON)}

In the CANON process, $\mathrm{NH}_{4}^{+}-\mathrm{N}$ is first converted to $\mathrm{NO}_{2}^{-}-\mathrm{N}$ by aerobic $A O B$, after which the $\mathrm{NO}_{2}^{-}-\mathrm{N}$ and remaining $\mathrm{NH}_{4}^{+}-\mathrm{N}$ are converted to $\mathrm{N}_{2}$ by anaerobic $A O B$ (Table 3) [76]. CANON has been a hot area of research in the wastewater treatment field nowadays. The CANON process provides several advantages, including less aeration demand, less sludge production, and no organic carbon consumption [32]. Liu et al. [77] studied the microbial diversity and population with the different influent $\mathrm{NH}_{4}^{+}$-Nin a CANON biofilter packed with volcanic filter. Biodiversity analysis showed that Nitrosomonasrelated aerobic $A O B$ and Planctomycetales-like anammox bacteria were dominant functional bacteria. Previous studies indicated that influent $\mathrm{NH}_{4}^{+}-\mathrm{N}$ concentration 
and temperature were two of the principal factors that constrained the CANON process to treat sewage. The decrease of $\mathrm{DO}$, influent $\mathrm{NH}_{4}^{+}-\mathrm{N}$, and temperature had a negative effect on certain $A O B$ and anammox bacteria, leading to either an acclimation of existing bacterial population to new conditions or a fluctuation of microbial community and population [77]. As noted by Liang et al. [78], high DO concentrations (around $5 \mathrm{mg} / \mathrm{L}$ ) of the influent were required to achieve high-rate nitrogen removal, and the ratio of air inflow to water inflow should be maintained at 28-40 for stable operation.

\section{Oxygen-Limited Autotrophic Nitrification-Denitrification (OLAND)}

In the OLAND process, $\mathrm{NH}_{4}^{+}-\mathrm{N}$ is autotrophically oxidized to $\mathrm{N}_{2}$ with $\mathrm{NO}_{2}{ }^{-} \mathrm{N}$ as the electron acceptor under oxygen-limited conditions (Table 3) [79]. Compared with a traditional nitrification-denitrification process, OLAND requires lower oxygen consumption (63\% lower), higher organic carbon degradation and removal efficiency, and lower operating cost [34]. De Clippeleir et al. [80] demonstrated the possibility of obtaining fully autotrophic TN removal in the OLAND biofilter through a coupling of aerobic $A O B$ and anoxic ammonium oxidizing or anammox bacteria $(A n A O B)$ activity. The abundance of aerobic $A O B$-AmoA, AnAOB-16SrRNA, and Nitrospira16 SrRNA was $2 \times 10^{2}, 9 \times 10^{3}$, and $2 \times 10^{2}$ copies/ng DNA.

The review on nitrogen removal and transformation processes reveals that $\mathrm{NH}_{4}^{+}-\mathrm{N}$ removal through nitrification and $\mathrm{NO}_{3}^{-}-\mathrm{N}$ removal through denitrification are considered satisfactory in biofilters. Anammox was a significant mechanism that accounted for robust $\mathrm{NH}_{4}^{+}-\mathrm{N}$ removal in biofilters. The coupled multipath interactions of nitrification, denitrification, and anammox processes were the primary reason that accounted for the robust nitrogen removal performance in biofilters. Although the newly discovered nitrogen pathways have a high potential for nitrogen removal, more research efforts are needed to realize the full-scale application of biofilters. In addition, the less-studied ANRA process may be an existing but previously underestimated pathway in biofilters. The newly discovered comammox process will provide a new appreciation of the nitrogen cycle in biofilters.

\section{Challenges and Perspectives}

Biofilters have been intensively studied and used as a promising technology to achieve sustainable nitrogen removal in an aquatic environment. The coupling of microbial nitrogen transformation processes in biofilters were the primary reason accounting for high removal efficiency of nitrogen in an aquatic environment. The traditional biofilters for nitrogen removal have been the combined application of nitrification and denitrification processes. New biofilters based on partial nitrification coupled with the anammox process seem to be more favorable. The coupling of anammox bacteria, $A O B$, and $A O A$ have been successfully achieved in a lab-scale biofilter. However, the presence of archaea has been reported in biofilters [7], but little detailed information of Archaea have been investigated. Thus, more investigation is needed to explore the applicability of the co-existence of archaea and anammox bacteria in biofilters.

The SNAD process in biofilters has been proved by molecular techniques and is a notable process for treating high $\mathrm{NH}_{4}^{+}-\mathrm{N}$ and low-carbon concentration wastewaters. The SNAD process needs the simultaneous presence of aerobic and anaerobic conditions to function well. The limited oxygen supply is needed to inhibit $N O B$ over the $A O B$ and to further avoid inhibition of anammox bacteria. Therefore, more investigation is needed to explore optimal conditions for such notable co-existence.

Over the past few years, denitrification has been known as the only key mechanism in $\mathrm{NO}_{3}^{-}-\mathrm{N}$ removal. The DNRA and ANRA processes may be an underlying mechanism response for $\mathrm{NO}_{3}^{-}-\mathrm{N}$ removal $[37,81]$. However, few investigations on DNRA and ANRA in biofilters have been reported. Thus, further research efforts are required to study the importance of DNRA or ANRA in the nitrogen balance. These efforts should include using stable isotope techniques $\left({ }^{15} \mathrm{~N}\right)$ to accurately evaluate the contribution of DNRA or ANRA for nitrogen removal.

In biofilter systems, biomass, density, and thickness of biofilm affect the substrate (i.e., $\mathrm{NH}_{4}^{+}-\mathrm{N}, \mathrm{NO}_{3}^{-}-\mathrm{N}$, and $\mathrm{NO}_{2}^{-}-\mathrm{N}$ ) conversion rate, thus affecting the removal efficiency of nitrogen. Most current studies on biofilters are mainly concentrated on the practical applications and optimal operating parameters, which are largely based on one-dimensional monitoring and manipulation of traditional bulk physical-chemical parameters with limited scope for characterizing biofilter microbiology [15]. Furthermore, research of the density, porosity, and pore structure of biofilms should also be taken into consideration to further enhance nitrogen removal and to polish effluent. In addition, the quorum-sensing bacteria produce and release chemical signal molecules termed autoinducers, whose concentrations increase as a function of increasing cell density [82]. The quorum sensing in bacteria is supposed to function as the key role in microbial attachment. Thus, more research is required to study the function of quorum sensing on microbial attachment.

\section{Conclusions}

The literature reports the operational adaptability and feasibility of biofilters for nitrogen removal. The coupled multipath interactions of nitrification, denitrification, and anammox processes were the primary reason accounting for robust nitrogen removal performance. The newly discovered nitrogen pathways such as SNAD, SHARON, CANON, and OLAND have a high potential for nitrogen removal. In order to achieve satisfactory nitrogen removal, future studies should focus on exploring the co-existence of 
archaea and anammox bacteria, optimizing the operational parameters of SNAD, exploring the contribution of DNRA or ANRA to nitrogen removal, and exploring the quorumsensing function on microbial attachment.

\section{Acknowledgements}

This work was supported by the Start-up Funds of Northwest A\&F University to Honglei Wang (Z109021610), Special-Funds of Scientific Research Programs of State Key Laboratory of Soil Erosion and Dryland Farming on the Loess Plateau (A314021403-C6), and the Key Project of China Spark Program (GL2015007).

\section{References}

1. WANG H.L., JI G.D., BAI X.Y. Enhanced long-term ammonium removal and its ranked contribution of microbial genes associated with nitrogen cycling in a lab-scale multimedia biofilter. Bioresour. Technol, 196, 57, 2015.

2. WANG H.L., JI G.D., BAI X.Y. Quantifying nitrogen transformation process rates using nitrogen functional genesin a multimedia biofilter under hydraulic loading rate constraints. Ecol. Eng, 82, 323, 2015.

3. ZHANG X., WU Y., GU B. Urban rivers as hotspots of regional nitrogen pollution. Environmental Pollution, 205, 139, 2015.

4. KANNAN D., NEDUNCHEZHIAN S., MANI N. Physicochemical characteristics of groundwater from Kumbakonam Taluk of Thanjavur District-Tamilnadu (India). International Letters of Chemistry, Physics and Astronomy, 59, 1, 2015.

5. BRATIERES K., FLETCHER T., DELETIC A., ZINGER Y. Nutrient and sediment removal by stormwater biofilters: A large-scale design optimisation study. Water Res, 42, 3930, 2008.

6. WIK T., Trickling filters and biofilm reactor modelling. Rev. Environ. Sci. Bio, 2, 193, 2003.

7. WANG H., JI G., BAI X. Distribution patterns of nitrogen micro-cycle functional genes and their quantitative coupling relationships with nitrogen transformation rates in a biotrickling filter. Bioresour. Technol, 209, 100, 2016.

8. JI G., HE C., TAN Y. The spatial distribution of nitrogen removal functional genes in multimedia biofilters for sewage treatment. Ecological Engineering, 55, 35, 2013.

9. VAN DEN AKKER B., HOLMES M., CROMAR N., FALLOWFIELD H. Application of high rate nitrifying trickling filters for potable water treatment. Water Res, 42, $4514,2008$.

10. JI G., TONG J., TAN Y. Wastewater treatment efficiency of a multi-media biological aerated filter (MBAF) containing clinoptilolite and bioceramsite in a brick-wall embedded design. Bioresour. Technol, 102, 550, 2011.

11. CALVOBADO L.A., PETTITT T.R., PARSONS N., PETCH G.M., MORGAN J.A., WHIPPS J.M. Spatial and temporal analysis of the microbial community in slow sand filters used for treating horticultural irrigation water. Appl. Environ. Microbiol, 69, 2116, 2003.

12. STROUS M., VAN GERVEN E., ZHENG P., KUENEN J.G., JETTEN M.S. Ammonium removal from concentrated waste streams with the anaerobic ammonium oxidation (anammox) process in different reactor configurations. Water Res, 31, 1955, 1997.

13. CAI Y.A., LI D., LIANG Y.H., ZENG H.P., ZHANG J. Autotrophic nitrogen removal process in a potable water treatment biofilter that simultaneously removes $\mathrm{Mn}$ and NH4+-N. Bioresour. Technol, 172, 226, 2014.

14. CHAUDHARY D.S., VIGNESWARAN S., NGO H.H., SHIM W.G., MOON H. Biofilter in water and wastewater treatment. Korean J. Chem. Eng, 20, 1054, 2003.

15. VAN DEN AKKER B., HOLMES M., PEARCE P., CROMAR N.J., FALLOWFIELD H.J. Structure of nitrifying biofilms in a high-rate trickling filter designed for potable water pre-treatment. Water Res, 45, 3489, 2011.

16. PAREDES D., KUSCHK P., MBWETTE T., STANGE F., MÜLLER R., KÖSER H., New aspects of microbial nitrogen transformations in the context of wastewater treatment -a review. Eng. Life Sci, 7, 13, 2007.

17. ZHANG Y., JI G.D., WANG R.J., Genetic associations as indices of nitrogen cycling rates in an aerobic denitrification biofilter used for groundwater remediation. Bioresour. Technol, 194, 49, 2015.

18. HASAN H.A., ABDULLAH S.R.S., KAMARUDIN S.K., KOFLI N.T., ANUAR N. Kinetic evaluation of simultaneous COD, ammonia and manganese removal from drinking water using a biological aerated filter system. Sep. Purif. Technol, 130, 56, 2014.

19. SHI Y.H., WU G.X., WEI N., HU H.Y. Denitrification and biofilm growth in a pilot-scale biofilter packed with suspended carriers for biological nitrogen removal from secondary effluent. J. Environ. Sci, 32, 35, 2015.

20. LI P., ZUO J., WANG Y., ZHAO J., TANG L., LI Z. Tertiary nitrogen removal for municipal wastewater using a solidphase denitrifying biofilter with polycaprolactone as the carbon source and filtration medium. Water Res, 93, 74, 2016.

21. ZHANG Y., CHENG Y., YANG C., LUO W., ZENG G., LU L. Performance of system consisting of vertical flow trickling filter and horizontal flow multi-soil-layering reactor for treatment of rural wastewater. Bioresour. Technol, 193, 424, 2015.

22. WANG Z., FEI X., HE S., HUANG J., ZHOU W. Comparison of heterotrophic and autotrophic denitrification processes for treating nitrate-contaminated surface water. Sci. Total. Environ, 579, 1706, 2017.

23. ZHANG Y., JI G., WANG R. Drivers of nitrous oxide accumulation in denitrification biofilters with low carbon: nitrogen ratios. Water Res, 106, 79, 2016.

24. JING Z.Q., HE R., HU Y., NIU Q.G., CAO S.W., LI Y.Y. Practice of integrated system of biofilter and constructed wetland in highly polluted surface water treatment. Ecol. Eng, 75, 462, 2015.

25. ZHANG,S., WANG Y., HE W., XING M., WU M., YANG J., GAO N., SHENG G., YIN D., LIU S. Linking nitrifying biofilm characteristics and nitrification performance in moving-bed biofilm reactors for polluted raw water pretreatment. Bioresour. Technol, 146, 416, 2013.

26. JI G., ZHI W., TAN Y. Association of nitrogen micro-cycle functional genes in subsurface wastewater infiltration systems. Ecol. Eng, 44, 269, 2012.

27. CUI J., ZHANG Y. Research on biotrickling filters for wastewater and odor treatment, CRC Press, 247, 2017.

28. GUILLÉN J.S., JAYAWARDANA L., VAZQUEZ C.L., DE OLIVEIRA CRUZ L., BRDJANOVIC D., VAN LIER J. Autotrophic nitrogen removal over nitrite in a sponge-bed trickling filter. Bioresour. Technol, 187, 314, 2015. 
29. CHATTERJEE P., GHANGREKAR M., RAO S. Development of anammox process for removal of nitrogen from wastewater in a novel self-sustainable biofilm reactor. Bioresour. Technol, 218, 723, 2016.

30. LIANG Y., LI D., ZHANG X., ZENG H., YANG Z., ZHANG J. Microbial characteristics and nitrogen removal of simultaneous partial nitrification, anammox and denitrification (SNAD) process treating low $\mathrm{C} / \mathrm{N}$ ratio sewage. Bioresour. Technol, 169, 103, 2014.

31. ZENG T.T., LI D., ZENG H.P., XIE S.B., QIU W.X., LIU Y.J., ZHANG J. Nitrogen removal efficiency and microbial community analysis of ANAMMOX biofilter at ambient temperature. Water Sci. Technol, 71, 725, 2015.

32. LIANG Y., LI D., ZHANG X., ZENG H., YANG Z., CUI S., ZHANG J. Nitrogen removal and microbial characteristics in CANON biofilters fed with different ammonia levels. Bioresour. Technol, 171, 168, 2014.

33. GONZÁLEZ-MARTÍNEZ A., CALDERÓN K., ALBUQUERQUE A., HONTORIA E., GONZÁLEZLÓPEZ J., GUISADO I., OSORIO F. Biological and technical study of a partial-SHARON reactor at laboratory scale: effect of hydraulic retention time. Bioproc. Biosyst. Eng, 36, 173, 2013.

34. WINDEY K., DE BO I., VERSTRAETE W. Oxygenlimited autotrophic nitrification - denitrification (OLAND) in a rotating biological contactor treating high-salinity wastewater. Water Res, 39, 4512, 2005.

35. GUILLÉN J.S., GUARDADO P.C., VAZQUEZ C.L., DE OLIVEIRA CRUZ L., BRDJANOVIC D., VAN LIER J. Anammox cultivation in a closed sponge-bed trickling filter. Bioresour. Technol, 186, 252, 2015.

36. VAN KESSEL M.A., SPETH D.R., ALBERTSEN M., NIELSEN P.H., DEN CAMP H.J.O., KARTAL B., JETTEN M.S., LÜCKER S. Complete nitrification by a single microorganism. Nature, 528, 555, 2015.

37. CANFIELD D.E., GLAZER A.N., FALKOWSKI P.G., The evolution and future of Earths nitrogen cycle. Science, 330, 192, 2010.

38. PETERSEN D.G., BLAZEWICZ S.J., FIRESTONE M., HERMAN D.J., TURETSKY M., WALDROP M. Abundance of microbial genes associated with nitrogen cycling as indices of biogeochemical process rates across a vegetation gradient in Alaska. Environ. Microbiol, 14, 993, 2012.

39. JURETSCHKO S., TIMMERMANN G., SCHMID M., SCHLEIFER K.H. Combined Molecular and Conventional Analyses of Nitrifying Bacterium Diversity in Activated Sludge: Nitrosococcus mobilis and Nitrospira -Like Bacteria as Dominant Populations. Appl. Environ. Microbiol, 64, 3042, 1998.

40. URAKAWA H., TAJIMA Y., NUMATA Y., TSUNEDA S. Low temperature decreases the phylogenetic diversity of ammonia-oxidizing archaea and bacteria in aquarium biofiltration systems. Appl. Environ. Microbiol, 74, 894, 2008.

41. POLY F., WERTZ S., BROTHIER E., DEGRANGE V. First exploration of Nitrobacter diversity in soils by a PCR cloning-sequencing approach targeting functional gene nxrA. FEMS microbiology ecology, 63, 132, 2008.

42. BAGCHI S., VLAEMINCK S.E., SAUDER L.A., MOSQUERA M., NEUFELD J.D., BOON N. Temporal and spatial stability of ammonia-oxidizing archaea and bacteria in aquarium biofilters. PLoS. One, 9, e113515, 2014.

43. VAN DONGEN U., JETTEN M.S., VAN LOOSDRECHT M. The SHARON ${ }^{\circ}$-Anammox ${ }^{\circledR}$ process for treatment of ammonium rich wastewater. Water Sci. Technol, 44, 153, 2001.
44. PHILIPS S., LAANBROEK H.J., VERSTRAETE W. Origin, causes and effects of increased nitrite concentrations in aquatic environments. R. Environ. Sci. Biotechnol, 1, 115, 2002.

45. KIM D.-J., LEE D.-I., CHA G.-C., KELLER J. Analysis of free ammonia inhibition of nitrite oxidizing bacteria using a dissolved oxygen respirometer. Environ. Eng. Res, 13, 125, 2008.

46. VADIVELU V.M., KELLER J., YUAN Z. Effect of free ammonia on the respiration and growth processes of an enriched Nitrobacter culture. Water Res, 41, 826, 2007.

47. EUISO C., DAEWHAN R., ZUWHAN Y., EUISIN L. Temperature effects on biological nutrient removal system with weak municipal wastewater. Water Sci. Technol, 37, $219,1998$.

48. WILLERS H., DERIKX P., TEN HAVE P., VIJN T. Nitrification limitation in animal slurries at high temperatures. Bioresour. Technol, 64, 47, 1998.

49. KIM D., CHANG J., LEE D., HAN D., YOO I., CHA G. Nitrification of high strength ammonia wastewater and nitrite accumulation characteristics. Water Sci. Technol, 47, 45, 2003.

50. GARRIDO J., VAN BENTHUM W., VAN LOOSDRECHT M., HEIJNEN J. Influence of dissolved oxygen concentration on nitrite accumulation in a biofilm airlift suspension reactor. Biotechnol. Bioeng, 53, 168, 1997.

51. DE BOER W., GUNNEWIEK P.K., LAANBROEK H. Ammonium-oxidation at low $\mathrm{pH}$ by a chemolithotrophic bacterium belonging to the genus Nitrosospira. Soil Biology \& Biochemistry, 27, 127, 1995.

52. JIMÉNEZ E., GIMÉNEZ J., RUANO M., FERRER J., SERRALTA J. Effect of $\mathrm{pH}$ and nitrite concentration on nitrite oxidation rate. Bioresour. Technol, 102, 8741, 2011.

53. ALLEMAN J. Elevated nitrite occurrence in biological wastewater treatment systems. Water Sci. Technol, 17, 409, 1985.

54. MULDER J., VAN LOOSDRECHT M., HELLINGA C., VAN KEMPEN R. Full-scale application of the SHARON process for treatment of rejection water of digested sludge dewatering. Water Sci. Technol, 43, 127, 2001.

55. BERNET N., DANGCONG P., DELGENÈS J.-P., MOLETTA R. Nitrification at low oxygen concentration in biofilm reactor. J. Environ. Eng, 127, 266, 2001.

56. SZOTA C., FARRELL C., LIVESLEY S.J., FLETCHER T.D. Salt tolerant plants increase nitrogen removal from biofiltration systems affected by saline stormwater. Water Res, 83, 195, 2015.

57. VEZZARO L., ERIKSSON E., LEDIN A., MIKKELSEN P.S. Quantification of uncertainty in modelled partitioning and removal of heavy metals $(\mathrm{Cu}, \mathrm{Zn})$ in a stormwater retention pond and a biofilter. Water Res, 46, 6891, 2012.

58. SHANAHAN J.W., SEMMENS M.J. Alkalinity and $\mathrm{pH}$ effects on nitrification in a membrane aerated bioreactor: An experimental and model analysis. Water Res, 74, 10, 2015.

59. ZHANG T., JIN T., YAN Q., SHAO M., WELLS G., CRIDDLE C., P FANG H. Occurrence of ammonia-oxidizing Archaea in activated sludges of a laboratory scale reactor and two wastewater treatment plants. J. Appl. Microbiol, 107, 970, 2009.

60. ZUMFT W.G. Cell biology and molecular basis of denitrification. Microbiol. Mol. Biol. R, 61, 533, 1997.

61. CAO Y., GREEN P.G., HOLDEN P.A. Microbial community composition and denitrifying enzyme activities in salt marsh sediments. Appl. Environ. Microbiol, 74, 7585, 2008. 
62. WANG H., JI G., BAI X., HE C. Assessing nitrogen transformation processes in a trickling filter under hydraulic loading rate constraints using nitrogen functional gene abundances. Bioresour. Technol, 177, 217, 2015.

63. FAULWETTER J.L., GAGNON V., SUNDBERG C., CHAZARENC F., BURR, M.D., BRISSON J., CAMPER A.K., STEIN O.R. Microbial processes influencing performance of treatment wetlands: a review. Ecol. Eng, 35, 987, 2009.

64. HAJAYA M.G., TEZEL U., PAVLOSTATHIS S.G. Effect of temperature and benzalkonium chloride on nitrate reduction. Bioresour. Technol, 102, 5039, 2011.

65. HEINEN M. Simplified denitrification models: overview and properties. Geoderma, 133, 444, 2006.

66. GLASS C., SILVERSTEIN J. Denitrification kinetics of high nitrate concentration water: $\mathrm{pH}$ effect on inhibition and nitrite accumulation. Water Res, 32, 831, 1998.

67. STROUS M., FUERST J.A., KRAMER E.H., LOGEMANN S., MUYZER G., VAN DE PAS-SCHOONEN K.T., WEBB R., KUENEN J.G., JETTEN, M.S. Missing lithotroph identified as new planctomycete. Nature, 400, 446, 1999.

68. BAE H., PARK K.-S., CHUNG Y.-C., JUNG J.-Y. Distribution of anammox bacteria in domestic WWTPs and their enrichments evaluated by real-time quantitative PCR. Process. Biochem., 45, 323, 2010.

69. FERNÁNDEZ I., DOSTA J., FAJARDO C., CAMPOS J., MOSQUERA-CORRAL A., MÉNDEZ R., Short-and longterm effects of ammonium and nitrite on the Anammox process. J. Environ. Manage, 95, S170, 2012.

70. TANG C.-J., ZHENG P., WANG C.-H., MAHMOOD Q. Suppression of anaerobic ammonium oxidizers under high organic content in high-rate Anammox UASB reactor. Bioresour. Technol, 101, 1762, 2010.

71. AKTAN C.K., YAPSAKLI K., MERTOGLU B. Inhibitory effects of free ammonia on Anammox bacteria. Biodegradation, 23, 751, 2012.

72. STROUS M., KUENEN J.G., JETTEN M.S. Key physiology of anaerobic ammonium oxidation. Appl. Environ. Microbiol, 65, 3248, 1999.

73. EGLI K., FANGER U., ALVAREZ P.J., SIEGRIST H., VAN DER MEER J.R., ZEHNDER A.J. Enrichment and characterization of an anammox bacterium from a rotating biological contactor treating ammonium-rich leachate. Arch. Microbiol, 175, 198, 2001.

74. LAN C.-J., KUMAR M., WANG C.-C., LIN J.-G. Development of simultaneous partial nitrification, anammox and denitrification (SNAD) process in a sequential batch reactor. Bioresour. Technol, 102, 5514, 2011.

75. HELLINGA C., SCHELLEN A., MULDER J.W., VAN LOOSDRECHT M., HEIJNEN J. The SHARON process: an innovative method for nitrogen removal from ammoniumrich waste water. Water Sci. Technol, 37, 135, 1998.

76. SLIEKERS A.O., DERWORT N., GOMEZ J.C., STROUS M., KUENEN J., JETTEN M. Completely autotrophic nitrogen removal over nitrite in one single reactor. Water Res, 36, 2475, 2002.

77. LIU T., LI D., ZENG H., LI X., ZENG T., CHANG X., CAI Y.A.. ZHANG J. Biodiversity and quantification of functional bacteria in completely autotrophic nitrogenremoval over nitrite (CANON) process. Bioresour. Technol, 118, 399, 2012.

78. LIANG Y., LI D., ZHANG X., ZENG H., ZHANG J. Performance and influence factors of completely autotrophic nitrogen removal over nitrite (CANON) process in a biofilter packed with volcanic rocks. Environ. Technol, 36, 946, 2015.

79. KUAI L., VERSTRAETE W. Ammonium removal by the oxygen-limited autotrophic nitrification-denitrification system. Appl. Environ. Microbiol, 64, 4500, 1998.

80. DE CLIPPELEIR H.E., COURTENS E., MOSQUERA M., VLAEMINCK S.E., SMETS B.F., BOON N., VERSTRAETE W. Efficient total nitrogen removal in an ammonia gas biofilter through high-rate OLAND. Environ. Sci. Technol, 46, 8826, 2012.

81. ZHI W., YUAN L., JI G., HE C. Enhanced long-term nitrogen removal and its quantitative molecular mechanism in tidal flow constructed wetlands. Environ. Sci. Technol, 49, 4575, 2015.

82. LV J., WANG Y., ZHONG C., LI Y., HAO W., ZHU J. The microbial attachment potential and quorum sensing measurement of aerobic granular activated sludge and flocculent activated sludge. Bioresour. Technol, 151, 291, 2014. 